IFN Working Paper No. 760, 2008

\title{
The Alert and Creative Entrepreneur: A Clarification
}

Israel M. Kirzner 


\title{
The Alert and Creative Entrepreneur: A Clarification
}

\author{
by \\ Israel M. Kirzner
}

August 11, 2008

\begin{abstract}
Israel M. Kirzner is the 2006 winner of The International Award for Entrepreneurship and Small Business Research (the FSF-Nutek Award). In this Prize Lecture he argues that a number of those who have commented on his work have misunderstood certain aspects of his theoretical system, and as a result the common distinction in the literature between "Schumpeterian" and "Kirznerian" entrepreneurs is flawed. He also argues that his understanding of the market process (set in motion by entrepreneurial decisions) provides a theoretical underpinning for public policy vis-àvis entrepreneurship. Professor Kirzner's main contributions to the economics of entrepreneurship were also presented and evaluated by Douhan, Eliasson and Henrekson (2007).
\end{abstract}

Keywords: Austrian economics; Economic development; Entrepreneurship; Small business economics. JEL Codes: B49; B52; B53; O31.

Professor Emeritus of Economics

New York University

1612 Forty-Eighth Street

Brooklyn, NY 11204-1126

Phone: +1-718-851-0071 
When I was awarded the 2006 FSF-NUTEK International Award for Entrepreneurship and Small Business Research, I certainly appreciated the great honor which this award implied for my work on entrepreneurial theory. But, I must confess, I was at the same time somewhat puzzled. This Prize, I had understood, was for work exploring the elusive sources of the entrepreneurial decision. Such work, it was hoped, may throw light on the secrets of successful entrepreneurship. Successful entrepreneurship plays an enormously significant role in driving economic development, growth, and in the achievement of the prosperous economy. It is therefore important to identify the human qualities that make for successful entrepreneurs, and the social and economic conditions needed to promote the emergence of successful entrepreneurship. This Prize, I understood, was thus part of a broad research initiative that might lead to public policies and educational programs that would in turn stimulate and encourage the entrepreneurial potential latent in society, and thus bring about the desirable economic results which successful entrepreneurship can generate.

But my own work has nothing to say about the secrets of successful entrepreneurship. My work has explored, not the nature of the talents needed for entrepreneurial success, not any guidelines to be followed by would-be successful entrepreneurs, but, instead, the nature of the market process set in motion by the entrepreneurial decisions (both successful and unsuccessful ones!). ${ }^{1}$ So that the thrust and character of my work on entrepreneurial theory did not, it would seem, fit the framework for this prize. Hence my initial puzzlement, referred to above. This paper seeks (a) to identify more carefully the sense in which my work on entrepreneurial theory does not throw light on the substantive sources of successful entrepreneurship, (b) to argue that a number of (sympathetic) reviewers of my work have somehow failed to recognize this limitation in the scope of my work (and that these scholars have therefore misunderstood certain aspects of my theoretical system), (c) to show that, despite all of the above, my understanding of the market process (as set in motion by entrepreneurial decisions) can, in a significant sense, provide a theoretical underpinning for public policy in regard to entrepreneurship. So that perhaps my work can be fitted into the framework for this Prize, after all.

\footnotetext{
${ }^{1}$ For the purpose of this paper, “my work” refers primary to Kirzner (1973), but also secondarily to papers included in Kirzner (1979, 1985, 1992, 2000).
} 
I have always emphasized that my own contribution is simply an expansion and deepening of insights articulated by my teacher, Ludwig von Mises. Yet, as we shall see, much of the following discussion relates to the similarities and the differences between my own portrayal of the entrepreneurial role, and that of Joseph A. Schumpeter 1912, 1942 in his celebrated, pioneering work on entrepreneurship. Although I have made earlier attempts to clarify these similarities and differences, ${ }^{2}$ I believe that this further attempt is still needed to clear up what I see as a certain confusion in the literature.

This paper thus addresses the somewhat embarrassing need to clarify what this writer himself meant in earlier writings. I thrust that this exercise in intellectual navel-gazing will be received with patient tolerance. There is a need to clarify the differences between the Misesian and the Schumpeterian understandings of the entrepreneurial market process. And perhaps the required character of a Prize Essay may soften, if not entirely excuse, the charge of excessive and exclusive focus upon the writer's own work.

\section{Individual Decisions and Market Outcomes}

It is, of course, basic to the microeconomic understanding of market phenomena, that such phenomena can be traced back to (and in fact consist of) individual market decisions. Changes in relative prices, changing patterns of outputs, changing methods of production, are all explained fully by referring back to individual consumers, resource-owners, and producer market decisions. Equilibrium microeconomic theory traces states of market equilibrium back to decisions made in the context of known, given and unchanging patterns of underlying variables (i.e., consumer tastes, resource availability, and technological knowledge). As is well known, in such equilibrium theory there is no scope for and no possibility of entrepreneurship. The introduction of entrepreneurship into the microeconomist's theoretical universe, opens up a new world in which there is scope for such disequilibrium phenomena as pure profit and loss, technological discoveries, innovation (other than the outcomes of planned research), and dramatic shifts in patterns of production. But one feature of microeconomic equilibrium theory does, of course, survive into the world of entrepreneurial change, viz. that market phenomena consist of the individual decisions of market participants

\footnotetext{
${ }^{2}$ See Kirzner (1982, 1999).
} 
(only that now, in the disequilibrium world, we have admitted entrepreneurial decision making into our system.)

For entrepreneurial theorizing based on Schumpeter's pioneering work, this has meant that (besides the "mechanical" constrained maximization governing decisions in the equilibrium world) we can now pay attention to the specific qualities which generate successful entrepreneurial decisions. Such qualities, emphasized by Schumpeter, include boldness, imaginativeness, and creativity. The Schumpeterian entrepreneur does not passively operate in a given world, he creates a world different from which he finds. He introduces hitherto undreamt of products, he pioneers hitherto unthought of methods of production, he opens up a new market in hitherto undiscovered territory. In so doing the entrepreneur is, in the Schumpeterian view, pushing (what might otherwise have been) an equilibrium market, away from equilibrium. His creativity disrupts what would otherwise have been a serene market. Because neo-Schumpeterian theory recognizes how important entrepreneurship is for economic growth, theorists have come to focus on the roots of the Schumpeterian qualities of the boldness and creativity, in order, hopefully, to understand how to stimulate entrepreneurdriven economic development - development that might jolt somnolent, poorly performing economies out of their present serene (but poverty stricken!) ruts. This explains the perceived need for a broad research program (mentioned at the outset of this paper) on the determinants of successful entrepreneurial decisions, in order to promote relevantly fruitful public policy.

\section{The Entrepreneur as Equilibrator}

In my earlier work on the entrepreneur (particularly in my 1973 book) based on insights articulated by Ludwig von Mises, I drew attention to a different way of seeing the impact of the individual entrepreneurial decision upon the market phenomena of the real world. In this perspective, the entrepreneur is not seen as disturbing any existing or prospective states of equilibrium. Rather he is seen as driving the process of equilibrium. In this process the market is, as it were, gravitating (through entrepreneurial activity) towards the hypothetical state of equilibrium (that is, the state which, in the (impossible!) absence of autonomous, exogenous changes in the underlying variables, might have eventually emerged). In my 1973 work this way of seeing the consequences of entrepreneurial behavior opened up an innovative way of understanding the active, competitive process (which, as is well-known, 
had been assumed away entirely in the then dominant equilibrium models of perfect (and monopolistic) competition). Moreover, in order to be able to focus more clearly upon the nature of the equilibrative competitive-entrepreneurial market process, my 1973 work deliberately abstracted from speculative market decisions. As a result, the entrepreneur who dominated my 1973 book did not need to be creative at all; he simply had to be alert to price differentials which others had not yet noticed. (Thus he had, for example, to be alert to ways of profitably producing existing-type goods by using existing, but as not yet widely known goods.) The central feature of successful entrepreneurship (i.e., entrepreneurship able to "notice” pure price differentials, and thus to move, equilibratively, towards their elimination) was thus not creativity (but alertness to already existing, but as yet widely unnoticed changes).

In order to identify the manner in which the market consequences of my entrepreneurs differ from those emphasized in Schumpeter's work, I emphasized how my entrepreneurs can be seen as responsible for equilibrating market movements (such as changing prices), in the absence of dramatic changes in product specifications or in production methods. My entrepreneurs were engaged in arbitrage, acting entrepreneurially even when they might not be seen as Schumpeterian “creators”.

In so emphasizing the difference between Schumpeter's theory of entrepreneurship and my own, I was motivated by my primary scientific objective. This was to understand the nature of the market process - even in its simplest conceivable contexts. The truth was (and is!) that standard microeconomic theory, because of its focus on competitive equilibrium, has been unable to account for the most basic of market-theoretical principles. Even in the simplest Marshallian demand-supply context, standard theory has not been able to explain how markets systematically gravitate towards the equilibrium states (relevant to the given conditions of those markets). ${ }^{3}$ The key to understanding the market process is to understand the dynamic character of market competition. But the neoclassical focus on perfect competition as an equilibrium state of affairs prevented appreciation of this insight. It was not until Hayek's pioneering, but insufficiently-appreciated work on the dynamically competitive market as a process of mutual discovery, that Austrian economics was able

\footnotetext{
${ }^{3}$ For a candid, sophisticated recognition of this failure, see Fisher (1983).
} 
explicitly to grapple with this embarrassing hiatus. It was particularly in the work of Ludwig von Mises that this writer discovered, in the Misesian entrepreneur and in the Misesian dynamically competitive process, what he believed (and believes) to be the true solution. My 1973 work was written in order to spell out this solution. For this purpose it was not necessary (and in fact it would have been a distraction!) to dwell on the qualities needed for creative (Schumpeterian) entrepreneurship. Quite the contrary, it was necessary to show how the systematic competitive entrepreneurial market process can be traced back to entrepreneurial decisions and even these do not display Schumpeterian equilibriumdisturbing creativity.

Not only did my work abstract from the creativity of real-world entrepreneurs, it did not even aim to exploring the roots and the determinants of individual entrepreneurial alertness. Its focus was upon the dynamic competitive-entrepreneurial process driven by such alertness. It was only because the nature of this process is seen more clearly by paying attention to entrepreneurial alertness, that it was necessary to identify its presence in the individual decision. At any rate I certainly did not throw any light on "how to be alert". It would thus seem that my work hardly fits within any broad research program concerned with the secret of entrepreneurial success. Hence the puzzlement mentioned at the outset of this paper.

In retrospect it is possible to see how all this led to certain significant misunderstandings on the part of a number of scholars who commented on my work. Certainly this writer must, because of his imperfect expository technique, bear much of the blame for this misunderstanding. Subsequent sections of this paper will explain how these misunderstandings arose. They will clarify the extent to which, in spite of the contrast with Schumpeter which I emphasized in 1973, the truth is that my understanding of the dynamic market process certainly can (and should!) also encompass the consequences of Schumpeterian entrepreneurship.

\section{Creativity and/or Alertness: The Misunderstandings}

My emphasis on the entrepreneur as the agent driving the competitive-equilibrative forces of the market, focuses attention on the entrepreneur not as a creator, but as being merely alert. His equilibrative role stemmed, not from his autonomously introducing change into existing 
market relationships, but from his ability to notice, earlier than others, the changes that have already occurred, rendering existing relationships inconsistent with the conditions for equilibrium. The discrepancies which the entrepreneur notices, appear in the form of profit opportunities. It is the entrepreneurial- competitive grasping of such perceived opportunities which drives the market towards the (relevant new) equilibrium configurations.

Now in the real, multi-period, world, all this takes the form, of course, of entrepreneurially speculative activity. As Ludwig von Mises (whose ideas I was, explicitly, expounding and developing) put it (von Mises 1952, p.190): "What makes profit emerge is the fact that the entrepreneur who judges the future prices of the products more correctly than other people do buys some or all of the factors of production at prices which, seen from the point of view of the future state of the market, are too low... This difference is entrepreneurial profit.” Notice that Mises makes no reference to entrepreneurial innovation, creativity, or the like. He refers only to the entrepreneur's ability to "see” future prices more correctly than others see them. My early work, seeking to distil this core insight of Mises' entrepreneurial view of the market, presented this entrepreneurial alertness in the context of the simplest, pure arbitrage, model - in which, for this stated expository reason, no scope for creativity was needed at all.

In retrospect it is perhaps not surprising that this generated the misunderstanding referred to above. What some readers understood was that in my theory, in contrast to that of Schumpeter, the real world entrepreneur operates purely as a "passive" noticer of alreadyoccurred changes. It came to be thought that the real world market entrepreneurial process which my theory was intended to explain, did not move as expressing the creative, innovative leaps of faith by visionary entrepreneurs impatient with the status quo. Rather, it was understood, my theory saw the movements of real world capitalism as merely the adjustments made by passively alert entrepreneurs, quick to grasp the pure profits generated by errors of others.

This understanding somehow crystallized into the conclusion that my work claims the existence of two alternative, mutually-exclusive ways of seeing the dynamic, entrepreneurial real world capitalist process: (a) a Schumpeterian view of this process as a series of disruptive episodes of “creative destruction”, one driven by creative, innovative, 
entrepreneurial ventures, or (b) as a view, attributed to this writer, in which movements are seen as equilibrative entrepreneurial reactions to autonomous changes in the underlying supply and demand conditions. Entrepreneurs are to be seen either as bold, disruptive, innovators, or as passively-alert, harmony-restoring responders to already-occurred changes. ${ }^{4}$

It is not difficult to se how readers might resist accepting such a claim. (And, of course, they would be absolutely right in doing so, if any such claim had in fact been made!) Casual observation surely confirms Schumpeter's insights into entrepreneurial creativity. Anecdotal evidence surely abounds to assure us that in real world capitalism change often, if not always, begins with entrepreneurial outside-the-box thinking regarding newly invented products, newly devised production techniques, and innovative penetration into hitherto untapped market territories. At the same time it is equally apparent that some entrepreneurial profit is indeed attributable to alert awareness of already-occurred changes in consumer preferences, changes in the availability of already-in-use resources, and the like. Apparently, there must be scope for both a creative ("Schumpeterian”) entrepreneur (one who generates pure profit) and a "passive”, alert (“Kirznerian”) entrepreneur (one who snuffs out given profit opportunities by promptly exploiting them).

Moreover, it can be argued, it seems reasonable to see the full dynamic of the capitalist system as being the outcome of two distinct kinds of entrepreneur-driven changes. A (“longer-run”?) dynamic reflecting the creative genius of Schumpeterian entrepreneurs, can be seen to exist along-side a (“short-run”?) dynamic in which “passive” (merely alert) entrepreneurs tend constantly to bring markets into alignment with new conditions and possibilities (including those opened up by the imaginative, creative, Schumpeterian

\footnotetext{
${ }^{4}$ Among those who challenge the sharpness of the contrast (which they read me as maintaining) between a "Schumpeterian" understanding of the real-world entrepreneurial-capitalist process, and the "Kirznerian" understanding - and who challenge, in particular, the claim (which they believed me to have made) that only one of these two understandings corresponds to reality - see Hébert and Link (1982, p. 99) and Boudreaux (1994). See also Loasby (1982, p. 224; 1989, p. 178). Holcombe (1998, p. 57) has argued that Schumpeter's views reflect his interest in economic growth, while my view reflects a focus on (short-run?) resource allocation. In several important papers Holcombe $(1999,2003)$ has perceptively explored the interface between Schumpeter's view and my own. He has valuably argued for an extension of my own approach that might show how an "alertness"-understanding of entrepreneurship can lead to the recognition that it is entrepreneurship itself (responding to discovered opportunities) which, by creating market possibilities, generates yet further entrepreneurial opportunities. The capitalist process can thus be seen as an entrepreneurially-driven series of opportunity creations. In this section of this paper, in referring to the unhappiness of critics (with the sharp distinction [held to be claimed by myself] between Schumpeterian creativity and entrepreneurial alertness to existing opportunities), I have in mind an underlying theme which, I believe, pervades the literature cited in this footnote. Important contributions to this literature are also Fu-Lai Yu (1998, 2001).
} 
innovators). So that acceptance of a possible (short-run?) equilibrative role for merely alert entrepreneurs (as elucidated in my work) does not require us to reject the Schumpeterian emphasis upon creativity (as, it was believed, my work does require).

\section{Creativity and/or Alertness: A Corrective Clarification}

But the truth is that views reflected in the preceding section have not fully understood my position. The "merely alert" entrepreneur identified in my work was never intended as an alternative to the creative, innovative Schumpeterian entrepreneur. (It was only the equilibrative impact of the alert entrepreneur that was contrasted with the distinctive impact which Joseph Schumpeter attributed to the activity of the creative entrepreneur.) My 1973 exposition of the role of the merely-alert entrepreneur was deliberately couched in the context of the very simplest theoretical model (it was thus constructed to be able to abstract not only from the creative element in real-world entrepreneurship, but even from the speculative element). ${ }^{5}$ But this did not imply any denial of the creativity of (or, the speculative element in) real-world entrepreneurship. It did not deny that, as a result of such creativity and speculation, the dynamics of capitalism can be seen as including movements (away from existing stable patterns of relationship) towards new, hitherto unimagined patterns for possible equilibration.

What I had glimpsed in 1973 was an insight which still remains largely unseen by economists. This was that the entrepreneurial-competitive market process which Ludwig von Mises had identified was driven by entrepreneurial perception of profit opportunities "waiting to be grasped". To be sure, such opportunities "exist" in the real world, only in the speculative sense (i.e., they can be, realized only in the future). But in a very relevant sense they "exist" now. That is, to the entrepreneur who sees such an opportunity, it appears in the form of an opportunity to buy and to sell at different prices. Granted, the opportunity to sell, at least, is one that will come into full reality only in the future. But, once again, to the entrepreneur who, piercing the fog of futurity, does now see that opportunity, it exists for him in virtually in the very same sense that opportunities simultaneously to buy and sell currency profitably in different foreign exchange markets, exist now for the pure arbitrageur.

\footnotetext{
${ }^{5}$ I have been criticized, by other Austrian economists, for failing to emphasize (as Mises himself did emphasize) the speculative element in entrepreneurship. The present discussion should help dispel the misunderstanding which underlies this criticism. See also Kirzner (1985, p. 44).
} 
Once the pure arbitrage element is recognized to exist in the speculative activities of entrepreneurs, the road is open to yet another recognition. This is the recognition that the bold, creative, innovative entrepreneur, too, is at a yet higher level of abstraction, also engaged in arbitrage. What he "sees" is that, by assembling available resources in an innovative, hitherto undreamt of, fashion, and thus perhaps converting them into new, hitherto undreamt of products, he may be able (in the future) to sell output at prices which exceed the cost of that output to himself. In all its manifestations, entrepreneurship identifies arbitrage opportunities; the entrepreneur's activities, like those of all arbitrageurs, tend to squeeze out those arbitrage-profits opportunities he has noticed (and which "alerted" him to their existence). He tends to drive up the prices in the markets in which he sells.

There is, of course, a profound philosophical question as to whether it is legitimate to see speculative entrepreneurial profit opportunities as "waiting” to be grasped. Certainly one may wish to say that in "seeing” such possibilities, the entrepreneur is in fact creating them rather than simply grasping that which already exists. My 1973 exposition, however, was not concerned with such almost-metaphysical questions. It was aiming at a down-to-earth understanding of the dynamic market process - one which clearly consists of movements responding to (existing or future) profit opportunities and somehow, but quite surely, succeeding in tending to eliminate imbalances in market activities. As Bastiat had pointed out more than a century earlier, the great city of Paris does get fed. Despite the absence of any central agency coordinating the flows of different foodstuffs into the metropolis, the market does, whether we understand it or not, succeed to a significant extent, in coordinating these flows. My 1973 work glimpses the explanation for all this in the role of entrepreneur seen in his essential role of arbitrageur.

To see things in this way did not (as the critics has somehow understood) mean that I was in any way denying the elements of boldness, creativity, and innovativeness which, in the real world, certainly do characterize entrepreneurial activity. Rather, my theory sees the Schumpeterian entrepreneur - with all his brash creativity - as being the agent who is responding to existing imbalances in the market. To be sure, to label a world as being in imbalance as compared with some hypothetical world operating with as yet undreamed of 
technological breakthroughs may seem to be using hindsight to stretch language. Yet, once these breakthroughs will have become commonplace, it will indeed seem retrospectively appropriate to describe the earlier, primitive, situation, as one pervaded by waste, one "waiting" to be corrected. The advantage to using language emphasizing alert perception of what "is", rather than language emphasizing the bold creaction of what as yet does not exist, is that the language of alertness enables us to see with clarity that there is a single explanation for all market movements. Such movements consist of entrepreneurial actions aiming to grasp perceived pure profit opportunities. Such pure profit opportunities present themselves in a dizzying multitude of forms - all of them consisting of price differentials. Such price differentials may exist in simple single-commodity or single-resource-service contexts, in which space- or knowledge-barriers have permitted price discrepancies to emerge. They may exist in intertemporal markets in which today's resource services do not accurately reflect the future strength of demand for the products being produced by these services. And, of course, (the most important for the Schumpeterian vision), price differentials may occur in contexts in which the entrepreneurs who are today buying resource services, do so in order to introduce dramatically more efficient methods of production.

My point was (and is) to draw attention to the key Misesian insight. This is that all these price differentials (both attributable to Schumpeterian creativity and those present in the simplest of arbitrage contexts) can and should be seen as examples of entrepreneurialarbitrage activity. Such activity drives prices systematically in directions tending to eliminate the price differentials (i.e., the opportunities for pure profit) which are, always, the sparks which ignite entrepreneurial attention, drive, and creativity.

\section{Creativity, Alertness and Public Policy: Puzzlement Dissolved}

We may go even further - in a direction which may perhaps help dissolve the puzzlement referred to at the outset of this paper. It is not merely the case that Schumpeterian creativity can be comfortably subsumed under the category of alertness (and thus be illuminatingly seen to be, in a sense, a response to earlier errors). It can be suggested, I will maintain, that a focus on the "alertness" aspect of (all) entrepreneurship, can help us understand how public policy may help promote that very Schumpeterian creativity (which I certainly do acknowledge, must be the major component of future dramatic leaps in economic 
development). Once we recognize the "alertness" element in Schumpeterian creativity, we must also recognize that the way in which policymakers understand the market economy, is likely to carry enormously significant implications for encouragement or discouragement of entrepreneurial creativity.

The essence of alertness is, after all, not efficiency of choice within an already perceived given framework. Alertness does not refer to diligence in research. (Research can occur within a given knowledge framework.) Rather, alertness refers to a sense of what might be "around the corner", i.e., the sense to notice that which has hitherto not been suspected of existing at all. We know very little that is systematic about what "switches on" alertness (to notice that which has been staring one in the face, but of the existence of which one has had no inkling. After all, we cannot deliberately search for something of whose very existence one has no inkling.) But it does seem intuitively obvious that alertness can be "switched off" by the conviction that external intervention will confiscate (wholly or in part) whatever one might notice. Surely what excites one antenna to "see" that which has hitherto entirely escaped one's attention, is the general sense that something of value may be within reach, if only one knew what it was. Surely, it is the general prospect of pure entrepreneurial profit available for the taking that inspires entrepreneurial alertness. Public policies which to any degree deaden the excitement inspired by the prospect of pure entrepreneurial profit, must surely, lower the level of entrepreneurial alertness.

To be sure, creativity is much more than alertness. But the creativity that drives profitwinning entrepreneurial behavior is a creativity that embraces alertness too - alertness to present and future price patterns, alertness to new technological possibilities, and alertness to possible future patterns of demand. Public policies which tend to promote alertness, are policies which tend to promote creativity.

So that elaboration of Misesian insights into the pure-arbitrage-character of the entrepreneurial decision can be fitted into a research program aiming at the encouragement of vigorous, creative entrepreneurial economic development, after all. 


\section{References}

Boudreaux, Donald (1994), "Schumpeter and Kirzner on Competition and Equilibrium.” In Peter J. Boettke and David L. Prychitko (eds.), The Market Process: Essays in Contemporary Austrian Economics. Aldershot: Edward Elgar.

Douhan, Robin, Gunnar Eliasson and Magnus Henrekson (2007), “Israel M. Kirzner: An Outstanding Austrian Contributor to the Economics of Entrepreneurship." Small Business Economics 29(1-2), 213-223.

Fu-Lai Yu, Tony (1998), "Economic Development in Latecomer Economies: An Entrepreneurial Perspective.” Development Policy Review 16(2), 265-280.

Fu-Lai Yu, Tony (2001), “Entrepreneurial Alertness and Discovery.” Review of Austrian Economics 14(1), 47-63.

Fisher, Franklin M. (1983), Disequilibrium Foundations of Equilibrium Economics. Cambridge and New York: Cambridge University Press.

Hébert, Robert F. and Albert N. Link (1982), The Entrepreneur. Mainstream Views and Radical Critiques. New York: Praeger.

Holcombe, Randall G. (1998), ”Entrepreneurship and Economic Growth.” Quarterly Journal of Austrian Economics 2(1), 45-62.

(1999), "Equilibrium versus the Invisible Hand.” Review of Austrian Economics 12(2), 227-243.

(2003), "The Origins of Entrepreneurial Opportunities.” Review of Austrian Economics 16(1), 25-43.

Kirzner, Israel M. (1973), Competition and Entrepreneurship. Chicago: University of Chicago Press.

(1978),'The Entrepreneurial Role in Menger’s System.” Atlantic Economic Journal 6(3), 31-45.

(1979), Perception, Opportunity and Profit. Studies in the Theory of Entrepreneurship. Chicago and London: University of Chicago Press.

(1982), "The Theory of Entrepreneurship in Economic Growth.” In

Calvin A. Kent, David L. Sexton and Karl H. Vesper (eds.), Encyclopedia of

Entrepreneurship, Englewood Cliffs. N.J.: Prentice-Hall.

(1985), Discovery and the Capitalist Process. Chicago and London:

University of Chicago Press.

(1995), “The Subjectivism of Austrian Economics.” In Gerrit Meijer

(ed.), New Perspectives on Austrian Economics. London and New York: Routledge.

Routledge.

(1992), The Meaning of Market Process. London and New York:

(1997), "Entrepreneurial Discovery and the Competitive Market

Process: An Austrian Approach.” Journal of Economic Literature 35(1), 60-85.

(1999), "Creativity and/or Alertness: A Reconsideration of the

Schumpeterian Entrepreneur.” Review of Austrian Economics 11(1-2), 5-17.

(2000), “The Limits of the Market: the Real and the Imagined.” In

Israel M. Kirzner (ed.), The Driving Force of the Market - Essays in Austrian

Economics. London: Routledge.

(2002), “Comment on ‘A Critique of Kirzner’s Finders-Keepers 
Defence of Profit'.” Review of Austrian Economics 15(1), 91-94.

Loasby, Brian J. (1982), “The Entrepreneur in Economic Theory.” Scottish Journal of Political Economy 29(3), 220-241.

(1989), The Mind and Method of the Economist. Aldershot: Edward Elgar.

Von Mises, Ludwig (1952), "Profit and Loss.” In Planning for Freedom and Other Essays and Addresses. $2^{\text {nd }}$ Edition. South Holland: Libertarian Press.

Schumpeter, Joseph A. (1934), The Theory of Economic Development. Cambridge, MA: Harvard University Press.

(1942), Capitalism, Socialism and Democracy. New York: Harper \& Row. 